\title{
Teaching and Learning with Smartphone: Qualitative Explorative Study from Pakistan
}

\author{
Dr. Rahman, Haji ${ }^{a}$ and Hameed, Mehtab ${ }^{b}$ \\ ${ }^{\mathrm{a}}$ Department of Management Sciences, University of Buner, KP, Pakistan, ${ }^{\mathrm{b}}$ Faculty of \\ Business Administration, Preston University Islamabad, Pakistan
}

\begin{abstract}
This paper investigates the perceptions of teachers and students about using smartphone for teaching and learning practices in private sector universities of Islamabad through cross-sectional based qualitative explorative study. Focus group interviews were conducted from teachers and students through self-selection sampling technique. Current study is guided by Grounded Theory for which semi-structured questionnaire was adopted and modified. The results suggested two categories of teachers. Realist teachers believe that they have to follow and act according to principles of reality that prevailes on ground. Idealist teachers believe that their job is to enlarge the intellectual capacity of students with focus on cognitive development rather vocational training. To sum up, integration of modern technologies like smartphone in higher education stimulates to adopt creative and innovative ways for teaching and learning practices because of its bilateral, media-rich and knowledge sharing nature thus necessary for gaining competitive advantage. Few restrictions were faced by researchers. The study is limited to city of Islamabad only. A practical implication of this study along with few recommendations for future research is also given.
\end{abstract}

Keywords: Teaching; learning; smartphone; perceptions; private universities. 


\section{Introduction}

This paper aims to find out the different perceptions of students and teachers with respect to using smartphone during teaching and learning at higher education classroom settings Need was felt to pursue a qualitative research in this perspective because world has adopted the nature of mobility (Odom, 2015), which stimulated both society and industry to react accordingly. According to Ally (2012) in education sector, digital libraries are accessed by learners through their mobiles and other educational resurces (Ally \& Tsinakos, 2014). Such educational technologies makes teaching and learning practices more effective (Richey, Silber \& Ely, 2008), however, its integration in the classroom setting is more important (Ross, Moorrison \& Lowther, 2010). In this connection, study of Berk (2010) indicated a positive correlation between technology and learning.

Successful educational innovation depends on teacher's personal willingness (Groff \& Mouza, 2008) and sense of professional responsibility (Vanderlinde \& Braak, 2011). Becker and Ravitz (1999) provided concept of constructivist teachers; having student oriented approach of teaching based on inquiry. Alternate to this, Niederhauser and Stoddart (2001) presented concept of behaviorist teachers; having traditional belief of teaching and learning with instructional methods. Montrieux, Vandertlinde, Scheliens and Marez (2015) contributed by giving concept of instrumental (behaviorist) and innovative (constructivist) teachers. The former did not changed their belief and teaching style whereas the later one have adopted the role as required by/for development of diverse students.

Millennials are accessing online course materials through smartphone (Lella, Lipsman \& Martin, 2015) due to its unique features like a phone, camera, watch, phonebook, flashlight, calendar, notebook, calculator and media player etc. Philosophy of Bring Your Own Device (BYOD) was highlighted by Akuity (2014) which was first reported in 2007 business forum where employees were allowed making use of personal smartphones and laptops etc for official tasks. Results of the survey conducted by educause in USA revealed that initially $86 \%$ students prefer laptop as primary computer device for education purpose but this trend has been shifted to tablets $15 \%$ and now highly preferred smartphone with $62 \%$ (Dahlstrom \& Bichsel, 2016). This is too high in higher education which clearly expresses wide acceptance of BYOD in education.

Higher Education Commisison (HEC) of Pakistan is further strengthening the initiative of Government of Pakistan regarding Prime Minister Youth Laptop Schemes which was launched in 2013 for only talented students of public sector universities for five years. This is a matter of great concern because talented students are also available in private sector universities as well. Laptops cannot be integrated in every class due to complex requirements of different disciplines. Additionally, not only students will feel overburden but also it will create congested environment if connectivity support is provided. Mobile 
tablets can also be used during classroom however handling/operating will be a problem while listening and capturing teachers knowledge. Alternatively, smartphone is a good option due to its safe handling and lighter weight. According to McDonald and Reushle (2002) flexibility is always demanded by students, so keeping students on safe side, teaches need to show flexibility and provide creative environment. This elasticity is a main driver of furnishing learning needs of diverse students effectively and efficiently (Yorke \& Thomas, 2003).

Problem is identified by thorough review of literature wrt education industry in Pakistan, where very little research is available. Foreign teachers takes initiative to provide flexible and technology supported creative environment to students to keep and retain their interest but unfortunately, in Pakistan, it is not like that. The gap between our technique of delivering and grasping lecture in comparison to other foreign countries in the world needs consideration because actual problem is less understanding of being change and digitized. Literature did not provide any clue regarding perceptions focusing this region therefore specific research is needed to explore teachers and students perceptions about using smartphone for teaching and learning in private sector universities of Pakistan. In order to answer aforementioned problem statement, grounded theory of Glaser and Strauss (1967) is being followed for exploring below mentioned queries:-

- How teachers role is perceived by students and teachers in smartphone integration?

- How students and teachers perceive such advancements in learning practice?

- What conditions can be perceived that support this teaching and learning practice?

- What benefits and challenges are perceived by the teachers and students?

\section{Research Methodology}

Following deductive method, cross-sectional based qualitative explorative study with focus group interviews were conducted through semi-structured questionnaire (illustrated in table 1) which was adopted and modified. Population comprises forty (15 teachers and 25 students) respondents recruited through self selection sampling technique from six (06) private sector universities of Islamabad i.e. Abasyn, CASE, FAST, IQRA, CUST and Preston. Major disciplines that were focused for this study; comprised of Management Sciences, Computer Sciences, International Relations and Psychology. Following Kruger and Casey's (2014) concept, six focus groups were organized for an interview of 60 minutes.

Asking questions slightly inspired the findings of Hattie (2008) claimed the role of teacher (RQ1), teaching and learning practice (RQ1\&2), need of professionalism (RQ3) while benefits and challenges (RQ4) as quoted by Odom (2015). Whole discussions were audiotaped and conversations were transcribed which was loaded into NVivo, qualitative data analysis computer software package through coding system. Following Miles and 
Huberman (1994) route, vertical (within-case) analysis was done through fixed set of paragraphs format. Horizontal (cross-site) analysis was done through systematically comparison of data of focus groups for their similarities and differences.

Table 1. Semistructured interview from teachers and students.

\begin{tabular}{|c|c|}
\hline Section & Questions Asked \\
\hline \multirow{2}{*}{$\begin{array}{l}\text { Intro } \\
(n=2)\end{array}$} & Please introduce yourself. \\
\hline & Using smatphone inside classroom adds value. Comment. \\
\hline \multirow{2}{*}{$\begin{array}{c}\text { Teaching } \\
\text { Practices } \\
(n=2)\end{array}$} & $\begin{array}{l}\text { How do you see your responsibility as a teacher / role of your teacher in } \\
\text { classroom? }\end{array}$ \\
\hline & Teachers have adequate skills to teach with smartphone. Comment. \\
\hline \multirow{4}{*}{$\begin{array}{c}\text { Learning } \\
\text { Practices } \\
(n=4)\end{array}$} & Using smartphone, I / students achieve better. \\
\hline & Using smartphone, students can grasp their lesson easily. \\
\hline & Using smartphone, it is fun to learn. \\
\hline & Using smartphone, I / students work more collaboratively with peers. \\
\hline \multirow{4}{*}{$\begin{array}{c}\text { Final } \\
\text { Questions } \\
(n=4)\end{array}$} & Sum up pros and cons of susing smartphone during classroom. \\
\hline & Have you faced some problems while using smartphone? \\
\hline & What are your expectations for the future? \\
\hline & Should smartphone be introduced by HEC in university classrooms? \\
\hline
\end{tabular}

\section{Results}

\section{RQ1:How teachers role is perceived by students and teachers in smartphone integration?}

Both teachers and students described two kinds of teaching styles, labeled by researchers as "realist teachers" (70\%) and “idealist teachers" (30\%). Researchers defined realist teachers as those who did not change their role and teaching style thus quoting that only difference is the addition of smartphone with updated knowledge having negative aspect of easy disitraction as well as no control over the class. Philosophical perspective in education named it as realism; underwhich such teachers believe that reality prevails in physical world where we live and knowledge is gained through reasons and experiences. They also feels that our job is to teach what course has been given to us as essential to develop their reasoning powers.

Alternatively, idealist teachers see themselves as coach because they believe that aim of education is to develop the intellectual capacity of students with focus on their cognitive development. Respondents believe that such advancements will explore their analytical, logical and conceptual skills during learning thus good investment for future. Philosophical perspective in education named it as idealism underwhich such teachers teach key concepts from classics, patiently guide them in search for truth and skillfully promote thinking in 
students through enhancing spirit of inquiry. Ultimate end result will be transferring of teacher based education (knowledge transmission) to focus on student learning.

\section{RQ2:How students and teachers perceive such advancements in learning practice?}

Respondents appreciate its added value wrt ease of use, speedy access, taking pictures and audio/video recording plus reduced weight of previously heavy bags. Majority students reported learning in interesting way because it will boost informal brainstorming sessions where students can not only easily argu, communicate but also their logical, analytical and reference based skills will be enhanced. In sum, it will increase the collaborative approach among students to share information with each other thus enhancing their self confidence and strong social influence among peer members.

\section{RQ3: What conditions can be perceived that support this teaching and learning practice?}

Respondents revealed administrative based organizational support, categorized by researchers as resource based approach and professionalism. Resource based approach was derived from Barney (1991) theory called Resource Based View (RBV) focusing on heterogenous bundle of resources that persist over time. Respondents perceived other conditions like high speed internet connectivity, strong network administration, customized software, security cameras and ethical guidelines/SOPs for monitoring and evaluation. Professionalism means develoiping adequate skills to operate smartphone easily in classroom supporting text material in terms of topic related videos, case studies, funny stories, market oriented assignments, individuals and group based presentations for skills enhancement.

\section{RQ4: What benefits and challenges are perceived by the teachers and students?}

Benefits perceived by teachers and students as (1) Enhancement of learner-centric-approch given by McQuiggen, Sabourin and Kosturko (2015). (2) Increase in collaborative interactive approach given by Yu (2012) which follows social development theory (SDT) of Russian psychologist Vygotsky's (1962) that social interaction influences cognitive developments. (3) Motivates students to learn given by Warnich and Gordon (2015). (4) Quick assessment of students in short time (Hussein (2015). (5) Increase teacher/students communication given by Stone (2014). He also prefers whatssapp, facebook, twitter, snapchat and remind.com in conjunction with virtual learning management system.

Challenges perceived by teachers and students as (1) Easy distraction with smartphone like twitter, instagram given by Gikas and Grant (2012). Few students revealed distraction, however, coming back to assigned task is also simple. (2) Miniature of screen is also paintaking for longer use inside classroom given by McQuiggen, Sabourin and Kosturko (2015). (3) Cost of and access to device may produce depths available in market. (4) 
Pregvailing attitudes and prejudices of teachers and students as some teachers prohibit use of cell phone in class which is also supported by few students.

\section{Discussions and Conclusions}

Results confirmed the driving role of teachers for successful implementations of technology to classroom (Chen, Looi \& Chen, 2009). In line with comprehensive literature and our individual practice of delivering lectures with smartphone, we believe that students will love this innovative type of learning where student engagement can be made through collaborative leanring exercises (Park, 2011). Some negative aspects like easy distraction (surfing google, facebook, twitter etc) and loss of control over the class (maintaining discipline and technology supported learning environment) may be raised. Wastage of time due to distraction will lead to indiscipline attitudes of both teachers and students towards each other could be the major risk. Regardless of small sample size, still respondents were influenced from this type of innovative teaching and learning methods. To conclude, using smartphone during class not only make it effective but also stimulating to reach mobile oriented inhabitants of this century.

\section{Limitations and Future Research}

This paper was restricted to private sector universities of Islamabad individuals. Apart from this, small sample size was taken into consideration due to some ground realities. Policy makers (HEC and University Management) should consider the pitfall highlighted for smooth integration in future. Study recommends not only greater sample size for in-depth analysis of the perceptions regarding this change in teaching and learning practices but also to have analysis of perceptions of public/private universities. It may be expanded to other medical, nursing, engineering, technical and vocational institutions as well.

\section{Research Implicaitons}

Academically, it provides avenues to the researchers to examine competitive advantages of this technology (smartphone) integration in classroom setting. From managerial perspective, if offers to recognize the possible use of technology in order to gian value added benefits like creativity, innovation, knowledge sharing and experience through formal or informal disucsisions and brainstorming.

\section{References}

Akuity (2014). Seven Stats About The Future of BYOD Retrieved from http://www.akuity.com/2014/03/17/seven-stats-about-the-future-of-byod/.

Ally, M. (2012). Education for all with mobile technology: the role of libraries. M-Libraries 3: Transforming Libraries with Mobile Technology, 1. 
Ally, M., \& Tsinakos, A. (Eds.) (2014). Increasing access through mobile learning. Vancouver, BC: Commonwealth of Learning Press.

Barney, J. (1991). Firm resources and sustained competitive advantage. Journal of management, 17(1), 99-120.

Becker, H. J., \& Ravitz, J. (1999). The influence of computer and Internet use on teachers' pedagogical practices and perceptions. Journal of research on computing in education, 31(4), 356-384.

Berk, R. A. (2010). How do you leverage the latest technologies, including Web 2.0 tools, in your classroom?. International Journal of Technology in Teaching \& Learning, 6(1): p.13.

Chen, F. H., Looi, C. K., \& Chen, W. (2009). Integrating technology in the classroom: a visual conceptualization of teachers' knowledge, goals and beliefs. Journal of Computer Assisted Learning, 25(5), 470-488.

Dahlstrom, E., \& Bichsel, J. (2016). ECAR study of undergraduate students and information technology. Research report. Louisville, CO: ECAR, October 2014. Disponível em http://www. educause. edu/ecar Acesso em: 22 fev.

Gikas, J., \& Grant, M. M. (2013). Mobile computing devices in higher education: Student perspectives on learning with cellphones, smartphones \& social media. The Internet and Higher Education, 19, 18-26.

Glaser, B., \& Strauss, A. (1967). The discovery of grounded theory Chicago. Adeline, USA.

Groff, J., \& Mouza, C. (2008). A framework for addressing challenges to classroom technology use. AACe Journal, 16(1), 21-46.

Hattie, J. (2008). Visible learning: A synthesis of over 800 meta-analyses relating to achievement. Routledge.

Hussein, B. A. (2015). A blended learning approach to teaching project management: A model for active participation and involvement: Insights from Norway. Education Sciences, 5(2), 104-125.

Krueger, R. A., \& Casey, M. A. (2014). Focus groups: A practical guide for applied research. Sage publications.

Lella, A., Lipsman, A., \& Martin, B. (2015). A Global Mobile Report: How Multi-Platform Audiences and Engagement Compare in the US, Canada, UK and Beyond.

McDonald, J., \& Reushle, S. (2002, December). Charting the role of the online teacher in higher education: Winds of change. In Proceedings ASCILITE 2002: 19th Annual Conference of the Australasian Society for Computers in Learning in Tertiary Education (pp. 431-440). Australasian Society for Computers in Learning in Tertiary Education (ASCILITE). 
McQuiggan, S., McQuiggan, J., Sabourin, J., \& Kosturko, L. (2015). Mobile learning: A handbook for developers, educators, and learners. John Wiley \& Sons.

Miles, M. B., \& Huberman, A. M. (1994). Qualitative data analysis: An expanded sourcebook. sage.

Montrieux, H., Vanderlinde, R., Schellens, T., \& De Marez, L. (2015). Teaching and learning with mobile technology: A qualitative explorative study about the introduction of tablet devices in secondary education. PloS one, 10(12), e0144008.

Niederhauser, D. S., \& Stoddart, T. (2001). Teachers' instructional perspectives and use of educational software. Teaching and teacher education, 17(1), 15-31.

Odom, D. (2015). Teaching with Smartphones in the Higher Education Classroom. AYME, $1-13$.

Park, Y. (2011). A pedagogical framework for mobile learning: Categorizing educational applications of mobile technologies into four types. The International Review of Research in Open and Distributed Learning, 12(2), 78-102.

Richey, R. C., Silber, K. H., \& Ely, D. P. (2008). Reflections on the 2008 AECT Definitions of the Field. TechTrends, 52(1), 24-25.

Ross, S. M., Morrison, G. R., \& Lowther, D. L. (2010). Educational Technology Research Past and Present: Balancing: Rigor and Relevance to Impact School Learning. Contemporary Educational Technology, 1(1).p.19.

Stone, B. (2014). “The teaching app at the head of the class," BloombergBusiness. Retrieved from http://www.bloomberg.com/bw/articles/2014-08-28/the-teaching-tooltopping-the- app-store/.

Vanderlinde, R., \& van Braak, J. (2011). A New ICT Curriculum for Primary Education in Flanders: Defining and Predicting Teachers' Perceptions of Innovation Attributes. Educational Technology \& Society, 14(2), 124-135.

Vygotsky, L.S. (1962). Thought and Language. Cambridge, MA: MIT Press.

Warnich, P., \& Gordon, C. (2015). The integration of cell phone technology and poll everywhere as teaching and learning tools into the school History classroom. Yesterday and Today, (13), 40-66.

Yorke, M., \& Thomas, L. (2003). Improving the retention of students from lower socioeconomic groups. Journal of higher education policy and management, 25(1), 63-74.

Yu, F., \& Conway, A. R. (2012). Mobile/smart phone use in higher education. Proceedings of the 2012 Southwest Decision Sciences Institute, 831-839. 